ANĐELA FRANČIĆ

Filozofski fakultet Sveučilišta u Zagrebu

Odsjek za kroatistiku

afrancic@ffzg.hr
DOI: http://dx.doi.org/10.17651/ONOMAST.63.4

Onomastica LXIII, 2019

PL ISSN 0078-4648

\title{
GRANICE MEĐU ANTROPONIMIJSKIM KATEGORIJAMA
}

Ključne riječi: onimizacija, apelativizacija, transonimizacija, transantroponimizacija, osobnoimensko-prezimenska homonimija

\section{UVOD}

Apelativom se označuju skupine istovrsnih denotata, a imenom (onimom) odabrani se denotat identificira i izdvaja od ostalih denotata iste vrste. Relativno ograničen broj imena i neograničen broj denotata te zakonitosti jezične ekonomije rezultiraju pojavnošću istoga jezičnog znaka u apelativnoj i imenskoj funkciji, odnosno istoga imenskog znaka u funkciji imenovanja denotata različite vrste.

U radu će se, na odabranim primjerima iz hrvatske antroponimije, analizirati granice među antroponimijskim kategorijama, s posebnim obzirom na granice između osobnih imena i prezimena. Pokazat će se da se bez širega konteksta, odnosno bez dodatnih informacija o denotatu, ne može uvijek sa sigurnošću odrediti kojoj antroponimijskoj kategoriji pripada antroponimijski leksem, odnosno ne može se osobno ime razlikovati od prezimena. S tim u vezi tematizirat će se homonimija u antroponimiji te upozoriti na posljedice koje ona ima za (antroponomastičku) komunikaciju.

\subsection{Granice između apelativa i antroponima}

Prije nego što prijeđemo na naslovom najavljenu temu, podsjetimo da granice između apelativa i antroponima nisu čvrste, odnosno nisu jednom zauvijek zadane. Poznat je proces antroponimizacije apelativa $(a \rightarrow A)^{1}$, npr.: naziv voća višnja $\rightarrow$ osobno ime Višnja; naziv zanimanja kovač $\rightarrow$ prezime Kovač; naziv tjelesne osobine debeli $\rightarrow$ nadimak Debeli; naziv kojim se označuje rodbinski odnos braco $\rightarrow$ nadimak Braco; (dijalektni) $)^{2}$ naziv prirodne pojave megla $\rightarrow$ prezime Megla itd.

$1 \mathrm{a}=$ apelativ, $\mathrm{A}=$ antroponim

2 Dijalektna riječ megla od standarednojezične magla razlikuje se po odrazu starohrvatskoga poluglasa $ə\left(<\right.$ psl. $\left.{ }^{*} b,{ }^{*} b\right)$. 
Pojava suprotna antroponimizaciji apelativa jest apelativizacija antroponima $(A \rightarrow a)$, npr: prezime Penkala $\rightarrow$ penkala 'naziv automatske mehaničke olovke', prezime Tesla $\rightarrow$ tesla 'naziv međunarodne jedinice za gustoću magnetskoga protoka'; etnonim Talijan $\rightarrow$ talijan 'naziv vrste kruha'; etnik Dalmatinac $\rightarrow$ dalmatinac 'naziv najpoznatije hrvatske autohtone pasmine pasa', etnonim $\mathrm{Bu}$ gar $\rightarrow$ bugar '(lokalni) ${ }^{4}$ naziv za uzgajivača ili prodavača povrća na tržnici' itd.

Antroponimizacijom se ne dokida motivirajući apelativ u apelativnome leksičkom podsustavu, niti apelativizacijom nestaje motivirajući antroponim u antroponimijskome leksičkom podsustavu, tj. oba leksema supostoje u leksičkome sustavu danoga jezika. Takvo se stanje (supostojanja) može s vremenom promijeniti. Promjenom izvanjezične zbilje neki apelativi postaju historizmi, ${ }^{5}$ npr. imenica knap (< njem. Knappe 'vojnik, štitonoša, pratilac') danas se više ne upotrebljava, ali ta imenica živi u prezimenu Knap (i izvedenicama Knapek, Knapić, Knapček). Unutarjezičnim promjenama neki apelativi postaju arhaizmi, ${ }^{6}$ npr. imenica cesar danas u hrvatskome standardnom jeziku živi u liku car, a hrvatsko prezime Cesar (i izvedenice Cesarec, Cesarić) čuvaju sjećanje na njezin nekadašnji lik. Prijelazom apelativa u pasivni leksik prezime postaje prepoznatljiv (prez)imenski leksem u leksičkome sustavu.

Apelativ onimizacijom, a antroponim apelativizacijom svoje dotadašnje apelativne, odnosno antroponimske značajke zamjenjuju značajkama leksičkoga podsustava dio kojega postaju. Tako se npr. apelativi antroponimijskoga ishodišta pišu malim početnim slovom (penkala), a antroponimi apelativnoga ishodišta velikim početnim slovom (Višnja); pri apelativizaciji i antroponimizaciji može doći do promjene gramatičkoga roda (ovaj Penkala — ova penkala, ova mrvica - ovaj Mrvica), sklonjiv apelativ može postati nesklonjiv antroponim (N lisac G lisca - N Ana Lisac G Ane Lisac), antroponim može sadržavati dijalektne značajke kojih je lišen standardnojezični apelativni lik (prezime Vučenik - učenik), apelativ i antroponim mogu imati različitu sklonidbenu paradigmu ( $\mathrm{N}$ draga $\mathrm{D}$ dragoj - N Draga $\mathrm{D}$ Dragi), različito se ponašati kad je riječ o gla-

3 Slavoljub Eduard Penkala (1871-1922.) hrvatski je inženjer kemije i izumitelj poljskoga podrijetla. Od osamdesetak njegovih izuma najpoznatiji je automatska mehanička olovka, kolokvijalno nazvana penkala. Istim se nazivom u žargonu označuje i nalivpero te kemijska olovka.

4 Riječ je o zagrebačkome lokalnom nazivu vezanom uz činjenicu da su ,tijekom čitavoga XX. stoljeća bugarski doseljenici na zagrebačkoj periferiji uzgajali povrće i prodavali ga na zagrebačkim tržnicama“" (Mršić, 2000, str. 60).

5 Historizmi su riječi ili izrazi pasivnoga leksika kojima se označuju zastarjele realije i pojmovi. Razlozi su njihova postanka izvanjezični.

${ }_{6}$ Arhaizmi su riječi ili izrazi pasivnoga leksika nastali zbog unutarjezičnih razloga (promjenom unutar samoga jezičnog sustava). U suvremenome aktivnom leksiku danoga jezika arhaizmi imaju izrazom potpuno ili djelomično različite sinonime. 
sovnim promjenama (rupčić — prezime Rubčić), imati različit naglasak (dijal. máček — prezime Màček) itd.

Onimizacija i apelativizacija neizostavna su tema temeljnih onomastičkih djela čiji autori zahvaćaju ukupnost imenskoga prostranstva (usp. npr. Superanskaja, 1973, str. 113-122; Superanskaja et al., 1986, str. 37-46; Blanár, 1996, str. 42-51; Šrámek, 1999, str. 55-56; Šimunović, 2005, str. 221-230).

\subsection{Granice među onimijskim kategorijama}

Ostavimo li po strani apelativni leksički podsustav i usredotočimo li se samo na onimijski, zapažamo da ni između onima različitih onimijskih kategorija nema čvrstih granica. O prijelazu iz jedne onimijske kategorije u drugu bez ikakvih formalnih preinaka svjedoče sljedeći odabrani primjeri iz hrvatske onimije: antroponim (prezime) Babic $\rightarrow$ toponim (hidronim) Babić, antroponim (prezime) Pevec $\rightarrow$ krematonim (ime trgovačkoga lanca) Pevec, antroponim (prezime) Zrinski $\rightarrow$ krematonim (ime alkoholnoga pića) Zrinski, toponim (hidronim) Una $\rightarrow$ antroponim (osobno ime) Una, toponim (horonim) Medimurje $\rightarrow$ krematonim (ime novina) Medimurje, mitonim Dijana $\rightarrow$ antroponim (osobno ime) Dijana...

Svi navedeni primjeri pripadaju čistoj transonimizaciji (transonimizaciji u užem smislu). ${ }^{7}$ Ona se može prikazati obrascem $O_{x} \rightarrow O_{y}$, u kojemu su $O_{x}$ i $O_{y}$ oznake dviju različitih onimijskih kategorija.

Transonim ostaje u području onimije, ali mijenja onimijsku kategoriju. Transonimizacijom se ne dokida motivirajući onim u prvotnoj onimijskoj kategoriji. Oba onima (motivirajući onim i transonim) supostoje, svaki u svojemu onimijskom podsustavu. Takvo se stanje (supostojanja) može s vremenom promijeniti. Nestane li jedan od njih, drugome se povećava obavijesnost o tome kojoj onimijskoj kategoriji pripada. Npr. osobno ime Pongrac (: lat. Pancratius) u međimurskoj onimiji danas „živi“ isključivo kao prezime, a osobno ime Jadan (: lat. Adamus) u međimurskome naselju Sveta Marija danas je prepoznatljivo kao muški singularizirani lik obiteljskoga nadimka Jadanovi.

7 O transonimizaciji su pisali mnogi slavenski onomastičari. Vrlo detaljan pregled radova čiji autori tematiziraju taj način postanka onima dala je Iveta Valentová (2012), a nedavno je o njoj pisala Urszula Bijak (2017). Za razliku od tradicionalnoga poimanja transonimizacije, prema kojemu se taj termin definira kao prijelaz onima iz jedne onimijske kategorije u drugu bez ikakvih formalnih preinaka, novije poimanje toga termina proširuje se i na slučajeve kada se transonim formalno razlikuje od motivirajućega onima. Transonimizaciju bez formalnih preinaka Šrámek naziva „čistom“ transionimizacijom (transonimizacijom u užemu smislu), a onu koja uključuje formalne preinake zove „proširenom“ transonimizacijom (transonimizcijom u širemu smislu) (Šrámek, 2003-2004, str. 505-506). 


\section{GRANICE MEĐU ANTROPONIMIJSKIM KATEGORIJAMA}

\subsection{Granice među osobnim imenima, prezimenima i nadimcima}

Pod antroponimijskom kategorijom razumijeva se jedna od triju osnovnih sastavnica antroponimije: osobno ime, prezime i nadimak. Te se antroponimijske kategorije, promatrajući ih u hrvatskome kontekstu, međusobno razlikuju:

- po vremenu pojavnosti u antroponimijskome sustavu: osobno je ime najstarija, a prezime najmlađa antroponimijska kategorija, dok nadimak (tj. pridjevak $)^{8}$ prethodi pojavi prezimena

- po zakonom (ne)propisanoj obveznosti: Zakonom o osobnom imenu ${ }^{9}(\mathrm{Na}$ rodne novine br. 118/12, dalje NN, 118/12) propisana je obveznost imanja osobnoga imena i prezimena; ${ }^{10}$ dakle, osobno ime i prezime sastavnice su službene komunikacije, a u neslužbenoj komunikaciji mogu se pojaviti sve tri osnovne antroponimijske kategorije

- po (ne)nasljednosti: nasljednost prezimena roditelja/roditeljā propisana je Zakonom o osobnom imenu, ${ }^{11}$ a osobno ime i nadimak uglavnom se ne nasljeđuju ${ }^{12}$

- po (ne)promjenjivosti: iako Zakon o osobnom imenu dopušta promjenu osobnoga imena i prezimena, ${ }^{13}$ službeno osobno ime ostaje uglavnom nepromijenjeno tijekom čitavoga života, dok se prezime nerijetko mijenja promjenom

8 Pridjevkom se u radu naziva dodatak osobnomu imenu u doprezimenskome razdoblju, a $n a-$ dimkom neobvezni antroponim u razdoblju prezimenske ustaljenosti. U hrvatskoj se onomastičkoj literaturi uz termin pridjevak (usp. npr. Šimunović, 2006, str. 368; Čilaš Šimpraga, 2007, str. 44; Frančić, 2009, str. 251) upotrebljava i termin priimak (usp. Šimunović, 2009, str. 174; Vidović, 2007), a ponekad se rabe oba usporedno bez objašnjenja razlike između njih (usp. Šimunović, 2006, str. 369; Brozović Rončević i Kapetanović, 2013).

9 Valja upozoriti na neusklađenost hrvatske zakonske i onomastičke terminologije. Ono što se u Zakonu naziva osobnim imenom („Osobno ime se sastoji od imena i prezimena“), onomastičari nazivaju službenom imenskom (antroponimijskom) formulom u kojoj je osobno ime, uz prezime, njezina obvezna sastavnica.

${ }_{10}$ Zakonski dio teksta koji se odnosi na obvezu imanja osobnoga imena i prezimena glasi: „Svaki građanin ima pravo i dužnost služiti se svojim osobnim imenom“ (NN, 118/12, članak 1).

${ }_{11}$ „Dijete može imati prezime jednog ili oba roditelja“ (NN, 118/12, članak 3).

12 Nasljednost je u stanovitoj mjeri svojstvena svim osnovnim antroponimijskim kategorijama, $\mathrm{s}$ tom razlikom što je ona, kada su u pitanju prezimena zakonom propisana, a ostale antroponimijske kategorije karakterizira relativna nasljednost, npr. potomak može dobiti osobno ime pretka (sin oca, kći majke, unuk djeda, unuka bake...); kadšto se može naslijediti i nadimak pretka. Dok je nasljednost osobnih nadimaka proizvoljna, mnogi su obiteljski nadimci nasljedni te su bili ili još uvijek jesu dijelom (polu)službene komunikacije (npr. u manjim sredinama gdje je više osoba $\mathrm{s}$ istim osobnim imenom i prezimenom, nadimak je nužan radi točne identifikacije). Obiteljski su se nadimci navodili u matičnim knjigama, školskim imenicima, na nadgrobnim spomenicima...

13 „Svaka osoba ima pravo promijeniti osobno ime“ (NN, 118/12, članak 6.). 
bračnoga stanja imenovane osobe; ${ }^{14}$ nadimak je promjenama podložniji od ostalih antroponimijskih kategorija te se može promijeniti više puta tijekom života

- po tome koliko kojih antroponima pojedinac može imati: svatko ima jedno osobno ime i jedno prezime, ${ }^{15}$ a pojedinci imaju jedan nadimak ili više njih

- po tome tko ih nadijeva: osobno ime nadijevaju uglavnom roditelji; imaju li roditelji različita prezimena, dogovorno odlučuju o tome čije će prezime dijete naslijediti; nadimak može nadjenuti bilo tko, a najčešće to čine osobe izvan obiteljskoga kruga

- po afektivnome naboju: službeno osobno ime i prezime nulte su afektivnosti, svako njihovo kraćenje ili duljenje u neslužbenoj komunikaciji u pravilu znači otklon u smjeru pozitivnoga ili negativnoga afektivnog naboja; afektivnost nadimka kreće se od pejorativnosti do meliorativnosti.

Da bismo govorili o granici među antroponimijskim kategorijama, moraju $\mathrm{u}$ antroponimijskome sustavu postojati barem dvije antroponimijske kategorije. Dakle, tek u razdoblju dvoimenske antroponimijske formule ${ }^{16}$ stvaraju se uvjeti razgraničenja njezinih sastavnica. Prvotnu dvoimensku antroponimijsku formulu čine osobno ime i (sintetski ili analitički) pridjevak, dok su sastavnice današ-

14 Žena i muškarac pri udaji/ženidbi svoje djevojačko/momačko prezime mogu zamijeniti prezimenom supružnika ili pak mogu svojemu djevojačkomu/momačkomu prezimenu dometnuti ili predmetnuti prezime supružnika.

15 Broj sastavnica osobnoga imena Zakonom o osobnom imenu nije ograničen: „Ime, odnosno prezime može se sastojati od više riječi. Osoba čije se ime ili prezime ili ime i prezime sastoji od više riječi, dužna je služiti se istim osobnim imenom u pravnom prometu. Ako osoba ima u matici rođenih upisano osobno ime koje se sastoji od više riječi, može izjavom odrediti s kojim će se riječima u osobnom imenu služiti u pravnom prometu“ (NN, 118/12. članak 2.). U neslužbenoj se komunikaciji u pravilu ne rabe višerječni antroponimi jer nisu funkcionalni s aspekta jezične ekonomije. Držimo bitnim istaknuti da pojedinac, bez obzira na broj sastavnica od kojih se njegovo službeno osobno ime sastoji, uvijek ima jedno osobno ime i jedno prezime.

${ }^{16} \mathrm{U}$ literaturi se često upotrebljava termin imenska formula/imenski obrazac (i autorica ovoga rada u svojim prijašnjim radovima služila se tim terminom). Budući da je riječ o formuli kojom se identificira osoba (a ne bilo koji denotat), držimo da je precizniji termin antroponimijska formula (usp. Podol'skaja, 1978, str. 35). Pritom ne mislimo da treba nužno taj termin ograničavati na polje službene uporabe (kao što to čini Podol’skaja definirajući antroponimijsku formulu: „Opredelennyj porjadok sledovanija različnyh vidov antroponimov i nomenov v oficial'nom imenovanii čeloveka dannoj nacional'nosti, soslovija, veroispovedanija v opredelennuju epohu“. Naime, i u neslužbenoj komunikaciji osobe imenujemo, ovisno o komunikacijskim okolnostima, jednom antroponimijskom kategorijom (npr. osobnim imenom, nadimkom ili prezimenom) ili kombinacijom dviju antroponimijskih kategorija (npr. osobnim imenom i obiteljskim nadimkom). Službenu antroponimijsku formulu, s obzirom na kategorije antroponima kojima njezine sastavnice pripadaju, zovemo i osobnoimensko-prezimenskom formulom. 
nje službene dvoimenske formule u Hrvata (kao i u većine europskih naroda) osobno ime i prezime. ${ }^{17}$

Iskustvo nas uči da neke antroponimijske lekseme prepoznajemo kao osobna imena (Boris, Damjan, David, Dominik, Filip, Grgur, Ivan, Katarina, Lovro, Marin, Martin, Nikola, Pavel, Radoslav, Radovan, Rajko, Slavica, Štefica, Vinko...), neke kao prezimena (npr. Brezinščak, Dominković, Dragić, Horvat, Janković, Ivić, Kovačić, Markić, Milić, Novaković, Perić, Radić, Zagorec, Zadravec...), a neke pak kao nadimke (Brko, Bucko, Burek, Cviker, Fanta, Grba, Griva, Krak, Mali, Mrav, Mrva, Piko, Šerif, Zec, Žuti...).

Međutim, zagledanjem u Leksik prezimena SR Hrvatske ${ }^{18}$ ili pak u njegovu noviju inačicu - Hrvatski prezimenik. Pučanstvo Republike Hrvatske na početku 21. stoljeća ${ }^{19}$ — osvjedočit ćemo se da su svi nabrojeni antroponimi kojima smo oprimjerili kategoriju osobnih imena te oni koji su nam poslužili kao primjer za nadimke potvrđeni i kao prezimena, a prezimena s osobnoimenskom osnovom i sufiksom -ić (dakle ona tvorbene strukture $\mathrm{O}_{\mathrm{OI}}^{20}+-i c ́$, kakva su Dragić, Ivić, Markić, Milić, Perić, Radićc ${ }^{21}$ u Rječniku hrvatskoga ili srpskoga jezi$k a$ nalazimo potvrđena i kao osobna imena. Dakle, isti antroponimijski leksem može imati funkciju različitih antroponimijskih kategorija. U nastavku ćemo se ograničiti samo na osobna imena i prezimena identična izraza, njihovu pojavnost u službenoj (osobnoimensko-prezimenskoj) antroponimijskoj formuli te propitati granice između njih.

\subsection{Granice između osobnih imena i prezimena}

Prezimena od osobnih imena najbrojnija su prezimenska skupina u hrvatskome antroponimikonu (Šimunović, 2006, str. 20). Većina njih nastala je proširenom

${ }_{17}$ U neslužbenoj komunikaciji, u kojoj dominiraju (jezičnom ekonomijom uvjetovane) jednostruke antroponimijske formule (osobno ime, prezime ili nadimak), rjeđe se pojavljuju dvoimenske antroponimijske formule sastavljene od osobnoga nadimka i prezimena (npr. Ćiro Blažević) te od singulariziranoga lika obiteljskoga nadimka i (službenoga ili neslužbenoga lika) osobnoga imena (npr. Pivarova Ilka, Ivicef Darko).

${ }_{18}$ Leksik prezimena SR Hrvatske (Putanec i Šimunović (ur.), 1976) sadržava abecednim slijedom popisana prezimena te podatke o broju njihovih nositelja i imena naselja u kojima su živjeli za popisa stanovništva 1948.

${ }_{19}$ U troknjižju Hrvatski prezimenik. Pučanstvo Republike Hrvatske na početku 21. stoljeća (Maletić i Šimunović (prir.), 2008) abecednim su slijedom popisana prezimena kojima su pridruženi podatci o broju njihovih nositelja i imena naselja u kojima su živjeli za popisa stanovništva 2001.

${ }^{20} \mathrm{O}=$ osnova, $\mathrm{OI}=$ osobno ime $\left(\mathrm{O}_{\mathrm{OI}}=\right.$ osobnoimenska osnova $)$

${ }^{21}$ Hrvatska prezimena tvorena od muškoga osobnog imena i složenoga prezimenskog sufiksa -ov-ić ,povukla“ su za sobom osobnoimenske izvedenice tvorene sufiksom -ić, te one analoški dobivaju funkciju prezimena. O njihovoj prvotnoj pripadnosti kategoriji osobnih imena svjedoče prezimena od njih izvedena (npr. Dragić-ević, Ivić-ević, Milić-ević) (Šimunović, 2006, str. 23). 
transonimizacijom (tj. sufiksalnom tvorbom) ${ }^{22}$ dok je manji dio prezimena $\mathrm{s}$ osobnim imenom u osnovi rezultat čiste transonimizacije ( $\mathrm{tj}$. asufiksalne tvorbe). ${ }^{23}$ Potonja prezimenska skupina bit će predmetom naše daljnje analize. $\mathrm{U}$ hrvatskoj onomastičkoj literaturi ta se prezimena uobičavaju nazivati i prezimena nalik na osobna imena (Moguš, 1982, str. 163-164; Frančić, 1989, str. 97-98; Šimunović, 1995, str. 74-76). Takva prezimena nisu svojstvena slavenskoj antroponimiji, osobito ne njezinu južnoslavenskom dijelu. Među južnoslavenskim jezicima ona su najzastupljenija u hrvatskome i slovenskome - u kojima se prezimena formiraju prije nego u ostalim (u kojima dominiraju patronimske prezimenske strukture). Ni na hrvatskome području takva prezimena nisu svugdje podjednako česta - rubna su područja (gdje su prezimena starija) njima bogatija od središnjih područja u prošlosti zahvaćenim imigracijama (Šimunović, 1995, str. 75).

Primjere hrvatskih prezimena nastalih transantroponimizacijom (Podol'skaja, 1978, str. 153 $)^{24}$ od osobnoga imena promotrit ćemo u svezi s osobnim imenom unutar službene antroponimijske formule.

\subsubsection{Osobnoimensko-prezimenska homonimija ${ }^{25}$}

Čista transantroponimizacija rezultira homonimnim parovima antroponima. Do homonimije osobnoga imena i prezimena može doći na dva načina:

${ }^{22}$ Od pedeset najučestalijih prezimena u suvremenome hrvatskom prezimeniku dvije trećine nastale su sufiksalnom tvorbom, to su: Marić, Jurić, Vuković, Marković, Petrović, Matić, Tomić, Pavlović, Božić, Blažević, Grgić, Pavić, Radić, Perić, Filipović, Lovrić, Vidović, Perković, Jukić, Barišić, Šimić, Nikolić, Mandić, Živković, Klarić, Barić, Martinović, Jurković, Stanić, Lukić, Matijević, Matković, Janković (Maletić i Šimunović (prir.), 2008, str. 115).

${ }^{23}$ Specifičan način postanka asufiksalnih prezimena (među njima i onih koja bivaju svedena na osobno ime) u nekim dijelovima Hrvatske jest desufiksacija (npr. Jurković $\rightarrow$ Jurko, Vukobratović $\rightarrow$ Vukobrat, Grgić $\rightarrow$ Grga, Ledenković $\rightarrow$ Ledenko, Sudarović $\rightarrow$ Sudar, Šupuković $\rightarrow$ Šupuk) (Bjelanović, 2007, str. 267, 284, 390).

${ }_{24}$ Podol'skaja (1978, str. 153) transantroponimizaciju definira kao „vid transonimizacii. Perehod antroponima odnogo vida v drugoj“. Iako ne daje daljnju podjelu (kao ni kod termina transonimizacija), primjeri koje navodi kazuju da se i tu može govoriti o čistoj (prezime Marks $\rightarrow$ osobno ime Marks) i proširenoj transantroponimizaciji (nadimak Orël $\rightarrow$ prezime Orlov, osobno ime Ivan $\rightarrow$ očestvo Ivanov).

${ }^{25}$ Homonimije se u svojim radovima dotiču mnogi onomastičari: podrobno ju opisuje npr. Superanskaja (1992), homonimnost imena kao sociolingvistički problem obrađuje Šimunović (1981), Blanár (1996, str. 139-141) preispituje postojeće klasifikacije homonima i nudi vlastitu itd. Zbog nevođenja računa o specifičnosti imena uopće, a time i specifičnosti imenske homonimije, neki lingvisti (pozivajući se na činjenicu da su imena znakovi sui generis čija se semantička transparentnost može utvrditi samo dijakronijski) niječu postojanje homonimije među imenima (Silić, 1992, str. 116). 
1. tako da se osobno ime, uza svoju primarnu funkciju, $\mathrm{u}$ istome antroponimijskom sustavu pojavi i u funkciji prezimena $(\mathrm{OI} \rightarrow \mathrm{P})^{26}$

2. tako da se prezime, uza svoju primarnu funkciju, u istome antroponimijskom sustavu pojavi i u funkciji osobnoga imena $(\mathrm{P} \rightarrow \mathrm{OI})$.

Dijakronijski gledano, prvi smjer tansantroponimizacije $(\mathrm{OI} \rightarrow \mathrm{P})$ događa se $u$ vrijeme formiranja prezimena, kada su osobna imena (uglavnom oca, rjeđe majke) bez ikakvih formalnih preinaka uzimana u službu prezimenske oznake, a do drugoga smjera tansantroponimizacije $(\mathrm{P} \rightarrow \mathrm{OI})$ dolazi u razdoblju kada prezimena $\mathrm{u}$ antroponimijskome sustavu egzistiraju kao obvezna antroponimijska kategorija (u Hrvata od 1780.). Do danas nisu provedena sustavna istraživanja koja bi pokazala rasprostranjenost i obuhvatnost obaju spomenutih načina transantroponimizacije u hrvatskome antroponimikonu, no i površnim uvidom u nj može se zaključiti da su prezimena od osobnih imena kudikamo češća nego osobna imena od prezimena. Potonja je pojava novijega datuma. Riječ je uglavnom o prezimenima poznatih osoba (npr: Nazor,${ }^{27}$ Tesla,${ }^{28}$ Puškin, ${ }^{29}$ Clinton $^{30}$ i sl.) koje roditelji izabiru za osobno ime svojemu potomstvu. ${ }^{31}$

${ }^{26} \mathrm{OI}=$ osobno ime, $\mathrm{P}=$ prezime

27 Vladimir Nazor (1876-1949.), hrvatski književnik.

${ }^{28}$ Nikola Tesla (1856-1943.), američki i hrvatski izumitelj srpskoga podrijetla.

29 Aleksandar Sergejevič Puškin (1799-1837.), ruski književnik.

${ }^{30}$ Bill Clinton (1946.), američki političar, bivši predsjednik SAD-a.

31 Osobna imena Nazor, Tesla, Puškin zabilježena su u Prosvjetinu imenoslovu (Bosanac, 1984), dok se Clinton spominje u novinskome članku (v. URL adresu u nastavku uz osobno ime Lovren). Nadijevanje prezimena poznatih osoba kao (novih ruskih) osobnih imena navode i Podol'skaja $(1978$, str. 153) te Superanskaja (1986, str. 47).

Unovije vrijeme mogu se unovinama pročitati vijesti o izboru prezimena poznatih nogometaša za osobno ime novorođenomu djetetu. Tako je npr. 2016. jedan dječak dobio ime Lovren prema Dejanu Lovrenu (https://vijesti.rtl.hr/novosti/zanimljivosti/2032685/najneobicnija-imena-dana-u-zagrebu-tijekom-godine-curice-minea-umou-cupic-santa-decki-clinton-dijamant-lovren-sandi/), a prezime najpoznatijega hrvatskog nogometaša Luke Modrića svojemu je sinu za osobno ime izabrao španjolski nogometaš Javier „Javi“ Márquez, te se dječak zove Modric Márquez (https:// www.index.hr/sport/clanak/igrac-granade-dao-sinu-ime-po-luki-modricu/880189.aspx).

Iz novina doznajemo i zanimljivu vijest da je bivši nogometaš Joaquín da Silva Medina sinu za osobno ime izabrao osobno ime i prezime (!) hrvatskoga nogometaša Roberta Prosinečkog, te dječakova atroponimijska formula glasi: Roberto Prosinecki da Silva Medina (https://www.jutarnji. hr/arhiva/i-brazilci-imaju-svog-prosineckog/3819201/).

Iako je u Francuskoj izbor osobnoga imena slobodan, sud je odlučio zabraniti roditeljima da djetetu nadjenu osobno ime čije su sastavnice prezimena dvojice francuskih nogometaša (Griezmann Mbappe) (https://www.slobodnadalmacija.hr/mozaik/zivot/clanak/id/594070/mislili-ste-da-je-39griezmann-mbappe39-cudno-procitajte-koja-su-sve-bizarna-imena-francuzi-spremni-nadjenuti-svojoj-djeci-i-shvatit-cete-zasto-je-sud-rekao-39ne39). 
S obzirom na pretpostavljenu veću zastupljenost homonimnih (osobnoimensko-prezimenskih) parova čija je prezimenska sastavnica rezultat čiste transantroponimizacije od osobnoga imena, $u$ antroponimikonu su moguće (i u hrvatskoj su antroponimiji potvrđene) ove pojave homonimnih parova u antroponimijskim formulama:

1. Homonimni parovi sastavnice su iste antroponimijske formule, npr. Boris Boris, Dominik Dominik, David David, Marijan Marijan. Antroponimijska se formula sastoji od jednoga homonimnog para.

2. Homonimni parovi sastavnice su dviju antroponimijskih formula:

a. formule se sastoje od dvaju homonimnih parova čiji parnjaci zauzimaju različito mjesto u strukturi svake od njih, npr. David Vinko, Vinko David.

b. svaka se formula sastoji od jednoga homonimnog para (osobnoimensko-prezimenskoga ili prezimensko-osobnoimenskoga), dok ostale dvije sastavnice tih formula nisu u homonimnome odnosu, npr. David Novak - Josip David; Stjepan Boris - Boris Horvat.

Zanimljiv je primjer svojevrsnoga homonimnoga lanca početna i završna karika kojega jesu antroponimijske formule čija samo jedna sastavnica ima svoj homonimni par, a nezavršne karike čine one antroponimijske formule čije obje sastavnice imaju svoj homonimni par (Frančić, 1998, str. 237-238):32

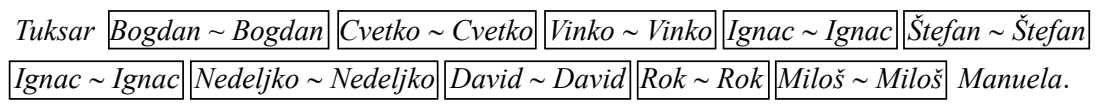

\subsubsection{Osobnoimensko-prezimenska homonimija i komunikacija}

Svaka homonimija, pa i ona u antroponimijskome sustavu, potencijalna je smetnja razumijevanju odaslane poruke. Sa stajališta odašiljatelja poruke problem homonimije ne postoji, a primatelju neonomastičke poruke pomaže komunikacijski kontekst, odnosno izvanjezična zalihost koja omogućuje normalno odvijanje komunikacije. Kada je o onimijskoj, u našemu primjeru osobnoimensko-prezimenskoj, homonimiji riječ, kontekst nam mnogo ne pomaže — imena se razlikuju zvukovno (fonijski): antroponim se prvo mora razgovjetno čuti, potom se mora razabrati je li riječ o osobnome imenu ili prezimenu. Osobnoimensko-prezimenska homonimija može otežati identifikaciju osoba, a identifikacija se u uređenim društvenim zajednicama vrlo davno nametnula kao izrazito društvena potreba - zbog nje su nastala prezimena.

32 Antroponimijske formule kojima se imenuju različite osobe odvojene su tildom ( ), a homonimni parnjaci, sastavnice antroponimijskih formula dviju osoba, uokvireni su. 
Ako isti antroponim obavlja funkciju obiju sastavnica antroponimijske formule (npr. Boris Boris), problem određivanja što je što u toj formuli ne postoji. Takva antroponimijska formula svojom neobičnošću obvezno na sebe svraća pozornost.

Problem se može pojaviti u osobnoimensko-prezimenskih formula koje u svojemu sastavu imaju čistom transantroponimizacijom od osobnoga imena nastalo prezime, $\mathrm{tj}$. kada osobno ime obavlja funkciju obiju sastavnica antroponimijske formule. Hrvatskoj tradiciji svojstven poredak sastavnica antroponimijske formule u kojemu osobno ime prethodi prezimenu (npr. Janko Matko) jedini je oslonac u određivanju što je u takvim formulama osobno ime, a što prezime. Međutim, kako se mogu sresti i slučajevi da pojedinci antroponimijsku formulu (pogrešno) izgovaraju ili pišu — s prezimenom na prvome mjestu (Matko Janko) — bez dodatne provjere ne možemo biti sigurni što je dotičnoj osobi osobno ime, a što prezime. A ta je informacija vrlo važna da bismo, uz ostalo, znali kako osloviti osobu kojoj se obraćamo. Naime, nije svejedno hoćemo li pri obraćanju sugovorniku upotrijebiti osobno ime ili prezime, npr. gospodine Matko ili gospodine Janko. Oslovljavanje osobnim imenom pretpostavlja bliskost, prijateljski odnos s imenovanom osobom, dok se prezimenom obraćamo nepoznatoj ili nadređenoj osobi, odnosno osobi s kojom nismo bliski.

$\mathrm{S}$ druge strane, ne raspolažemo li potpunom antroponimijskom formulom imenovane osobe nego samo njezinim prezimenom, također se možemo naći u neprilici kako ju osloviti. U hrvatskome službenom prezimenskom sustavu nema tzv. ženskih prezimena ${ }^{33}$ (svojstvenih službenoj antroponimiji nekih slavenskih jezika), pa samo prezime u nominativnome obliku uskraćuje informaciju o spolu imenovane osobe (za razliku od npr. slovačkih prezimena ženskih osoba koja se tvore sufiksom -ova (npr. Kohútová, Slivková, Trimajová, Smejsová, Markechová) ${ }^{34}$ hrvatska prezimena Kanižaj, Jurić, Slavica, Srpak ne pružaju podatak o spolu svojega nositelja). A ta nam je informacija važna da bismo npr. uopće znali sročiti pozdravnu formulu pri pismenome obraćanju - Poštovani gospodine / profesore/direktore Juriću ili Poštovana gospođo / profesorice/ direktorice Jurić.

${ }^{33}$ U povijesnoj antroponimijskoj građi te u suvremenoj neslužbenoj komunikaciji takva prezimena postoje (usp. npr. Putanec, 1968, str. 48-49, Gluhak, 2001). U novije je vrijeme zabilježena njihova uporaba u publicističkome stilu hrvatskoga standardnog jezika, npr. samo ženskim prezimenom katkad se imenuju političarke: Kosorova/Kosorica (Jadranka Kosor), Pusićeva/Pusićka (Vesna Pusić); sportašice: Vlašićka (Blanka Vlašić), Perkovićka (Sandra Perković); glumice: Violićeva/Violićka (Nina Violić); pjevačice: Badrićka (Nina Badrić), Šuputica (Maja Šuput)...

${ }^{34}$ Milan Majtán ističe da se „u hovorovej slovenčine a v slovenských nárečiach využivajú aj prechyl'ovacie prípony $-k a$, -ovka, na strednom a na východnom Slovensku -ul'a, -an̆a, -icha, na západnom Slovensku prípona -ena; Král'ka, Kupcovka, Blažkovka, Blažkul'a, Kujčena, Jackaňa, Bačicha, Fedoricha, Hricicha a pod.“ (Majtán, 2018, str. 9). 
Ponekad čak ni puna antroponimijska formula, sastavljena od osobnoga imena i prezimena, ne pruža informaciju o spolu imenovane osobe - Borna Francetić, Vanja Kramarić, Ivica Grubeša, Matija Kedmenec, Saša Pavlić... Sastavnica svih navedenih antroponimijskih formula, uz prepoznatljiv prezimenski leksem, jest osobno ime koje se nadijeva i muškim i ženskim osobama. Istraživanje je pokazalo da su takva osobna imena značajkom suvremenoga hrvatskog antroponimikona (Frančić, 2002, str. 81).

S obzirom na to da hrvatski Zakon dopušta i dvostruka ${ }^{35}$ (i višestruka) osobna imena te dvostruka (i višestruka) prezimena, među antroponimijskim formulama pretkazivi su i primjeri tipa: Ivan Vinko Boris. Nikakvo onomastičko znanje ne može nam pomoći da odgonetnemo ima li osoba koja se imenuje spomenutom antroponimijskom formulom jednostruko osobno ime (Ivan) i dvostruko prezime (Vinko Boris) ili dvostruko osobno ime (Ivan Vinko) i jednostruko prezime (Boris).

Nijedan od navedenih primjera ne dovodi u pitanje pripadnost onimijskoga leksema antroponimiji, nego njegovu pripadnost određenoj antroponimijskoj kategoriji.

Činjenica da pripadnost određenoj antroponimijskoj kategoriji nije implicitno svojstvo antroponimijskih leksema, uzrok je nesigurnosti pri određivanju motivacije prezimena tipa Glavina, Okan, Zubac, Golubić, Slaviček. Pitanje je jesu li ta prezimena nastala od najstarijih tipova osobnih imena motiviranih nazivima dijelova tijela (glava, oko, zub) ili nazivima ptica (golub, slaviček) ili su pak nadimačkoga postanja (nadimak osobi velike glave, istaknutih očiju ili zubi, osobi koja je nježna poput goluba ili lijepo pjeva poput slavuja).

\section{UMJESTO ZAKLJUČKA}

Konstataciju da su granice između apelativa i onima te između pojedinih onimijskih kategorija ponekad teško razlučive, možemo ponoviti i kada je riječ o razgraničenju među antroponimijskim kategorijama. Postojanje znatnoga broja hrvatskih prezimena nastalih čistom transantroponimizacijom od osobnih imena može otežati onomastičku komunikaciju, koja u takvim slučajevima zahtijeva dodatne informacije o imenovanome. Nositelji takvih prezimena trebali bi $\mathrm{s}$

${ }^{35}$ Za osobno ime koje se sastoji od jedne riječi rabimo termin jednostruko osobno ime, a osobno ime koje sa sastoji od dviju ili više riječi od kojih svaka za sebe u osobnoimenskome sustavu može funkcionirati kao jednostruko osobno ime rabimo termine dvostruko osobno ime i višestruko osobno ime (analogno tomu govorimo o jednostrukome i dvostrukome prezimenu). U hrvatskoj onomastičkoj literaturi u navedenome značenju sreću se i termini jednočlano i dvočlano osobno ime (prezime), jednorječno, dvorječno i višerječno osobno ime (prezime) te udvojeno osobno ime (prezime). 
posebnom pomnjom birati osobna imena svojemu potomstvu i pri izboru nastojati izbjegavati ona osobna imena koja se $u$ antroponimijskome sustavu sredine u kojoj žive pojavljuju i u prezimenskoj službi. S komunikacijskoga gledišta pogotovo nije funkcionalno izabrati prezimenu istovjetan osobnoimenski lik, osim ako takvim izborom ne želimo svratiti pozornost na imenovanu osobu. Mnogo je drugih načina kojima pojedinac može privući na sebe pozornost, stoga bi sastavnicama službene antroponimijske formule trebalo omogućiti da nesmetano obavljaju svoju identifikacijsku i diferencijacijsku funkciju, zbog čega su, uostalom, (antrop)onimi i nastali.

\section{LITERATURA}

Bijak, U. (2017). Transonimizacja, czyli „wędrówki nazw” [Transonymisation, or the "Migration of Names"]. Folia onomastica Croatica, 26, str. 1-14.

Bjelanović, Ž. (2007). Onomastičke teme [Onomastic Topics]. Zagreb: Hrvatska sveučilišna naklada.

Blanár, V. (1996). Teória vlastného mena (Status, organizácia a fungovanie v spoločenskej komunikácii) [The Theory of Proper Names (Status, Organisation, Functioning in Social Communication)]. Bratislava: Veda, vydavatel'stvo Slovenskej akadémie vied.

Brozović Rončević, D., Kapetanović, A. (2013). Tvorba i motivacija starohrvatskih priimaka [The Formation of and Motivation behind Old-Croatian Nicknames]. U: M. Turk (ur.), A tko to ide/A hto tam idze?: Hrvatski prilozi XV. Međunarodnom slavističkom kongresu [And, Say, Who Goes There?: Croatian Contributions to the 15th International Congress of Slavists] (str. 39-51). Zagreb: Hrvatsko filološko društvo - Hrvatska sveučilišna naklada.

Bosanac, M. (1984). Prosvjetin imenoslov [Dictionary of Names of Prosvjeta]. Zagreb: Prosvjeta.

Čilaš Šimpraga, A. (2007). Razvoj prezimenskoga sustava na Miljevcima [Development of the Family Names Classification in Miljevci]. Rasprave Instituta za hrvatski jezik i jezikoslovlje, 33 , str. 41-65.

Frančić, A. (1989). Prezimenski mozaik Međimurske Bistrice danas [The Mosaic of the Family Names of Bistrica in Međimurje Today]. Rasprave Zavoda za jezik, 15, str. 93-113.

Frančić, A. (1998). Imensko-prezimenska homonimija [Homonymy of First Name and Family Name]. U: K. Gadanji (ur.), VI. Međunarodni slavistički dani [6th International Slavic Days] (str. 234-242). Sambotel - Pečuh: Hrvatski znanstveni zavod - Visoka nastavnička škola u Sambotelu.

Frančić, A. (2002). Uvid u osobna imena rođenih 2001 [Insight into First Names of Children born in 2001]. Folia onomastica Croatica, 11, str. 77-93.

Frančić, A. (2009). Onomastička svjedočenja o hrvatskome jeziku [Onomastic Evidence of the Croatian Language]. U: A. Bičanić (ur.), Povijest hrvatskoga jezika, knjiga 1, srednji vijek [History of the Croatian Language in the Middle Ages] (str. 221-259). Zagreb: Croatica.

Gluhak, A. (2001). O hrvatskim prezimenima ženskima i dvostrukima [About Croatian Female and Double Family Names]. Folia onomastica Croatica, 10, str. 67-82.

Majtán, M. (2018). Naše priezviská [Our Family Names]. Bratislava: VEDA, vydavatel'stvo Slovenskej akadémie vied.

Maletić, F., Šimunović, P. (prir.). (2008). Hrvatski prezimenik. Pučanstvo Republike Hrvatske na početku 21. stoljeća [Croatian Lexicon of Family Names: Population of the Croatian Republic at the Beginning of the 21st Century]. Zagreb: Golden marketing — Tehnička knjiga. 
Moguš, M. (1982). Prezimena nalik na osobna imena [Family Names that Look like First Names]. Onomastica Jugoslavica, 10, str. 163-164.

Mršić, D. (2000). Eponimski leksikon [Lexicon of the Eponyms]. Zagreb: Matica hrvatska.

Osnoven sistem i terminologija na slovenskata onomastika [A Basic System and Terminology of Slavic Onomastics]. 1983. Skopje: MANU.

Podol'skaja, N.V. (1978). Slovar' russkoj onomastičeskoj terminologii [Dictionary of Russian Onomastic Terminology]. Moskva: Izdatel'stvo „Nauka”.

Putanec, V. (1968). Pavao Vitezović (1652-1713) kao onomastičar i antroponimija u „Lexicon latino-illyricum“ (17.-18. st.) [Pavao Vitezović (1652-1713) as an Onomastician and Anthroponymy in „Lexicon latino-illyricum“ (17.-18. cent.)]. Rasprave Instituta za jezik, 1, str. 45-88.

Putanec, V. (1976). Esej o jezičnom znaku i onomastici te o antroponimiji u Hrvatskoj [The Essay on the Linguistic Sign and Onomastics and about the Anthroponymy in Croatia]. U: V. Putanec i P. Šimunović (ur.), Leksik prezimena Socijalističke Republike Hrvatske [Lexicon of Family Names of the Socialist Republic of Croatia] (V-XIV). Zagreb: Institut za jezik — Nakladni zavod Matice hrvatske.

Putanec, V., Šimunović, P. (ur.). (1976). Leksik prezimena Socijalističke Republike Hrvatske [Lexicon of Family Names of the Socialist Republic of Croatia]. Zagreb: Institut za jezik - Nakladni zavod Matice hrvatske.

Rječnik hrvatskoga ili srpskoga jezika [Dictionary of the Croatian or Serbian Language], 1-23 (1880-1976). Zagreb: JAZU.

Silić, J. (1992). Status idionima u jeziku [Status of the Idionyms in the Language]. Radovi Zavoda za slavensku filologiju, 27, str. 115-122.

Superanskaja, A.V. (1973). Obščaja teorija imeni sobstvennogo [General Theory of Proper Names]. Moskva: Izdtel'stvo „Nauka“.

Superanskaja, A.V. et al. (1986). Teorija i metodika onomastičeskih issledovanij [Theory and Methodology of Onomastic Researches]. Moskva: „Nauka“.

Superanskaja, A.V. (1992). Omonimija v onomastike [Homonymy in Onomastics]. Folia onomastica Croatica, 1, str. 29-42.

Šimunović, P. (1981). Sinonimnost i homonimnost imena kao sociolingvistički problem [Synonimity and Homonymity as a Sociolinguistic Problem]. Hrvatski dijalektološki zbornik, 5, str. 145149.

Šimunović, P. (2006). Hrvatska prezimena [Croatian Family Names]. Zagreb: Golden marketing - Tehnička knjiga.

Šimunović, P. (2009). Uvod u hrvatsko imenoslovlje [Introduction to Croatian Onomastics]. Zagreb: Golden marketing — Tehnička knjiga.

Šrámek, R. (1999). Úvod do obecné onomastiky [Introduction to General Onomastics]. Brno: Masarykova univerzita.

Šrámek, R. (2003-2004). Transonymizace v propriální nominaci [Transonymisation in Proprial Nomination]. Folia onomastica Croatica, 12-13, str. 499-508.

Valentová, I. (2012). Transonymizácia — jeden zo spôsobov rozširovania propriálnej lexiky [Transonymisation - One of the Ways of Spreading Onymic Lexis]. Slovenská reč, 77, 5-6, str. 319-330.

Vidović, D. (2007). Prilog proučavanju odraza svetačkog imena Juraj u hrvatskoj antroponimiji [A Contribution to the Study of the Reflection of the Saint's Name Juraj in Croatian Anthroponimy]. Rasprave Instituta za hrvatski jezik i jezikoslovlje, 33, str. 431-447.

Zakon o osobnom imenu [Law on Personal Name]. (2012). Narodne novine, br. 118/12, https:// narodne-novine.nn.hr/clanci/sluzbeni/2012_10_118_2550.html

https://www.jutarnji.hr/arhiva/i-brazilci-imaju-svog-prosineckog/3819201/ (pristupljeno: 14. travnja 2019.) 
https://www.index.hr/sport/clanak/igrac-granade-dao-sinu-ime-po-luki-modricu/880189.aspx (pristupljeno: 14. travnja 2019.)

https:/www.slobodnadalmacija.hr/mozaik/zivot/clanak/id/594070/mislili-ste-da-je-39griezmann-mbappe39-cudno-procitajte-koja-su-sve-bizarna-imena-francuzi-spremni-nadjenuti-svojoj-djeci-i-shvatit-cete-zasto-je-sud-rekao-39ne39 (pristupljeno: 14. travnja 2019.)

https://vijesti.rtl.hr/novosti/zanimljivosti/2032685/najneobicnija-imena-dana-u-zagrebu-tijekomgodine-curice-minea-umou-cupic-santa-decki-clinton-dijamant-lovren-sandi/ (pristupljeno: 14. travnja 2019.)

\title{
SUMMARY
}

\author{
BOUNDARIES BETWEEN ANTHROPONYMIC CATEGORIES
}

In the introduction, examples from the Croatian language are used to exemplify the anthroponymization of appellatives (e.g. appellative kovač $\rightarrow$ family name Kovač), appelativization of anthroponyms (e.g. family name Penkala $\rightarrow$ appellative penkala) and transonymization (e.g. hydronym Una $\rightarrow$ first name Una). All of the listed transitions represent evidence that there are no firm boundaries between the onymic and appellative lexicon, nor within the onymic lexicon.

The central part of the study is dedicated to the so-called pure transanthroponymization of the type first name Vinko $\rightarrow$ family name Vinko. Pure transanthroponymization results in different combinations of homonymic pairs of anthroponyms in the anthroponymic formula/anthroponymic formulae (e.g. David David; David Vinko, Vinko David; David Novak - Josip David). Given that context does not contribute to the correct understanding of the message transmitted by the anthroponymic formula in the case of first name-family name homonymy, possible consequences of this homonymy for onomastic communication are emphasised. Also listed are examples of anthroponymic formulae of the Saša Pavlić type (it is impossible to distinguish whether the person is male or female from the first name) and Ivan Vinko Boris (it is impossible to distinguish whether the person has two first names or two family names from the anthroponymic formula) which also "stifle" the onomastic information.

The author concludes that the boundaries between first names and family names are not fixed and cautions of the need to carefully select the first name of a child bearing a family name created by the pure transanthroponymization of a first name.

Keywords: onymization, appelativization, transonymization, transanthroponymization, first name-family name homonymy

\section{STRESZCZENIE}

\section{GRANICE MIĘDZY KATEGORIAMI ANTROPONIMICZNYMI}

We wstępnej części pracy zaprezentowano przykłady z leksyki chorwackiej dokumentujące proces antroponimizacji apelatywów (np. apelatyw kovač $\rightarrow$ nazwisko Kovač), apelatywizacji antroponimów (np. nazwisko Penkala $\rightarrow$ apelatyw penkala) oraz transonimizacji (np. hydronim Una $\rightarrow$ imię $U n a$ ). Wszystkie wymienione przejścia są dowodem na to, że nie ma ostrej granicy pomiędzy leksyką onimiczną i apelatywną, ani wśród klas leksyki onimicznej. 
Zasadnicza część artykułu poświęcona jest tzw. czystej transantroponimizacji typu imię Vin$k o \rightarrow$ nazwisko Vinko. W wyniku takich procesów dochodzi później do różnych kombinacji homonimicznych par antroponimów w zestawieniach typu: David David; David Vinko, Vinko David; David Novak - Josip David). Biorąc pod uwagę fakt, że w przypadku homonimii imienia oraz nazwiska kontekst nie pomaga we właściwym zrozumieniu komunikatu zawartego w zestawieniu antroponimicznym, wskazane zostały konsekwencje, jakie ta homonimia może mieć dla komunikacji. Wymieniono również przykłady zestawień antroponimicznych typu Saša Pavlić (na podstawie imienia nie można stwierdzić, czy mowa o mężczyźnie czy kobiecie) oraz Ivan Vinko Boris (trudno rozstrzygnąć, czy osoba nosi dwa imiona czy jest dwojga nazwisk), które „tłumią” informację onimiczną.

Autorka dochodzi do wniosku, że granice między imieniem a nazwiskiem nie są ostre oraz zwraca uwagę na potrzebę przemyślanego dobierania imienia dziecku, które dziedziczy nazwisko utworzone od imienia w procesie czystej transantroponimizacji.

Słowa tematyczne: onimizacja, apelatywizacja, transonimizacja, transantroponimizacja, homonimia imienia i nazwiska 